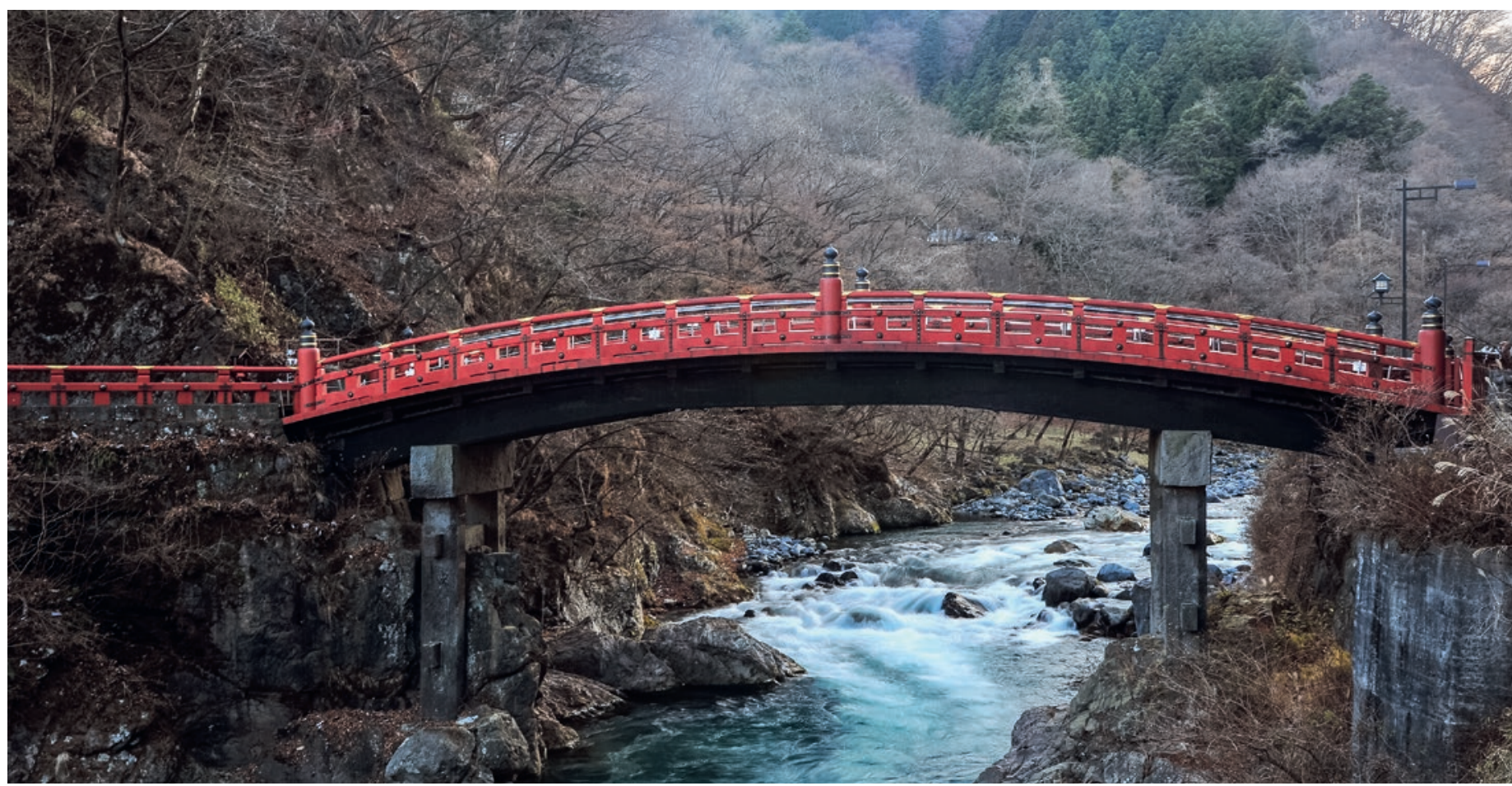

"Sacred bridge», Nikko, Japan.

\title{
The Bridges
}

\section{André Simon}

Dr. med., Facharzt für Allgemeine Innere Medizin, Mitglied FMH, Zürich

Dr. med. André Simon

Allgemeine Innere Medizin

Dörflistrasse 14

CH-8057 Zürich

andre.simon[at]hin.ch
The great Renaissance painter and sculptor Michelangelo has recommended: «The greatest danger for most of us is not that our aim is too high and we miss it, but that it is too low and we reach it." Therefore, my ultimate fictional goal is very, very, very high:

It is to create imaginary BRIDGES.

A bridge that unifies North and South.

A bridge that unifies East and West.

A bridge that ties the insights of ancient world philosophers and the way of the life in the $21^{\text {st }}$ Century.

We are told to never cross a bridge until we come to it, but this world is owned by the men who have "crossed bridges", in their imagination, far ahead of the crowd.

Those thinkers help us during our lifetime.

Life is a bridge between inexperience and the knowledge.

Wishful thinking for the $21^{\text {st }}$ Century would be:

A golden bridge of tolerance, which passes over the deep gap

that divides neighbors' beliefs from ours. Each day crossing it, is a happy day.

\section{Author's note:}

The reverse of all denomination of Euro banknotes bear different types of the stylized bridge illustrations. These bridges are "imaginary», and do not represent the existing monuments. However, the message is clear; the bridges bring the slight contribution to the unification of Europe.

\section{Credits}

() Porbital | Dreamstime.com, icon image 